\title{
Quality of Jam Made from Banana King's Peel
}

\author{
Putu Eka Wirawan, I Nyoman Sudiarta \\ Sekolah Tinggi Pariwisata Bali International \\ Denpasar, Indonesia \\ wirawanputu@gmail.com
}

\begin{abstract}
Jam is a food product with the consistency of gel or semi-solid made from pureed soup. Indonesian people with their increasing business schedule getting used to replace their breakfast menu with bread and jam. Utilization of banana peels in Indonesia has not been used for real, merely thrown away as organic waste or used as animal feeds. By looking at the banana peel waste processing is still low or minimal, this study utilizes waste banana peel, especially banana king's peel into refined products by process it into jam. The purpose of this study was to determine the utilization of quality of jam made from banana king's peel. This is a qualitative research, the data in this study were obtained from the data test instrument research. The data have been collected and processed, the data test instrument research. The data have been collected then processed, percentage, and presented in the form of bar chart. As the conclusion of this research is the result from the panelists "Quality of Jam made from Banana King's Peel" in general are looking for average value as a control variable obtain the final value of $73.4 \%$, taste got $87.5 \%$, aroma got $75 \%$, color got $67.8 \%$, and texture got $62.5 \%$.
\end{abstract}

\section{Keywords - Utilization, Banana King's peel, J am}

\section{INTRODUCTION}

\section{A. Background}

Nowadays, the majority of Indonesian people with their increasing business schedule getting used to replace their breakfast menu with bread and jam. Dietary changes have led to the increasing needs of jam with the huge public interest in the bread and butter as a complement. Jam is a food wet spring, which can be smeared, made from fruit processing, sugar with or without the addition of permitted food additives (BSN, 2008). In principle, almost all types of fruits can be made as jam, especially fruits that contain pectin. Pectin is a polysaccharide compound useful to form a gel with sugar in acidic conditions. In this research, will conduct by making of jam from banana peels and will be made with other ingredients based on recipe of jam in general. This research conducted in order to get result of jam qualified and will be reviewed from several aspects such as: taste, aroma, color, and texture. Banana peels were used in this research is the skin of the plantain, because it is thicker than another banana peel and has higher starch content than another banana skin. From the chemical composition, nutritional content of banana peel quite complete such as: carbohydrates, fats, protein, calcium, phosphorus, iron, vitamin $\mathrm{B}$, vitamin $\mathrm{C}$, water and dye carotenoids (Munadjim, 1998). Manufacture of jam made from banana king's peel besides to utilizing banana king's peel waste in which is still minim processing, also to increase the value of banana king's peel itself (Noviagustin, 2008).

\section{B. Research Problem}

Considering the background above, there is question formulated: How does the quality of jam made from banana king's peel in terms of flavor, aroma, texture, color and expiration date?

\section{Benefits of research}

Academic benefits of this research to the reader, both the students and public, can determine the quality of jam made from banana king's peel and can choose the jam made from banana king's peel as a complement for bread.

\section{LITERATURE REVIEW}

\section{A. Previous study}

There are two related research results in supporting this research. First was written by Adipura (2014) entitled "Studi Eksperimen Pembuatan Selai Dengan Bahan Dasar Tape Ketan Hitam dan Tape Ketan Kuningan serta Daya Terima Konsumennya". Second was written by Noerhatati (2009) entitled "Pembuatan Selai Salak (Salacca Edulis Reinw): Kajian Dari Penambahan Natrium Benzoat dan Gula yang Tepat Terhadap Mutu Selai Salak Selama Penyimpanan". Viewed from both studies above, if it is associated with the equationie in terms of focus experiments in making jam. If viewed from the difference that can be seen from the use of different materials.

\section{B. Concepts}

This research uses the concept of Sugiyono (2010) about the experimental methods and Mulyatiningsih (2012) about ADDIE design models which consists of five main phases or stages that is Analyse, Design, Development or Production, Implementation or Delivery and Evaluation.

\section{METHODS}

\section{A. Location}

The location of this research is in the kitchen laboratory of The Bali International Institute of Tourism located at Kecak Street, East Gatot Subroto 12, Denpasar, Bali. 


\section{B. Assessment of the Reference Product (Analyze)}

In the manufacture of jam, researcher compared several of the jam recipes as a study reference recipe from different references. In the design phase of product, was made jam recipe with basic ingredients of banana king's peel recipe based on a predetermined standard reference.

\section{Data Analysis Techniques}

This research uses two types of data, they are: qualitative data proposed by Strauss dan Corbin (2003) in this research, has been described the results of jam quality made from banana king's peel in terms of flavor/taste, color, texture, aroma, and expiration date also quantitative data proposed by Muslich (2010) in this research, data have been collected and processed was obtained from the questionnaire by giving rating of any statement based on the interval score and percentage. In this case the researchers collected data from the test results will be given to the organoleptic and four expert judgment. The respondents only choose the answers that have been provided in the organoleptic test, which have been prepared based on the Likert scale measurement and assessment of products consists of several aspects such as organoleptic test of flavor/taste, aroma, color and texture.

\section{RESULTS AND DISCUSSION}

\section{A. Results}

This research was conducted to determine the jam quality made from banana king's peel in terms of flavor, color, aroma and texture. The results of this experiment were then tested by four panelists from people who are experts in 2culinary in The Bali International Institute of Tourism to assess the quality of organoleptic test (taste, color, aroma and texture). The ideal score for each instrument is $4 \times 4=16$ ( 4 is top score and 4 is the number of panelists) Table I.

TABLE I. DATA ASSESSMENT OF JAM MADE FROM BANANA KING'S PEEL

\begin{tabular}{|c|c|c|c|c|c|}
\hline \multirow{2}{*}{$\begin{array}{l}\text { Panelist } \\
\text { numbers }\end{array}$} & \multicolumn{4}{|c|}{ Experiment score } & \multirow{2}{*}{ total } \\
\hline & flavor & aroma & color & texture & \\
\hline 1 & 4 & 4 & 3 & 3 & 14 \\
\hline 2 & 3 & 2 & 2 & 3 & 10 \\
\hline 3 & 4 & 4 & 3 & 2 & 13 \\
\hline 4 & 3 & 2 & 3 & 2 & 10 \\
\hline total & 14 & 12 & 11 & 10 & 47 \\
\hline
\end{tabular}

Based on the table I, the data obtained is 47 , therefore, the score of jam made from banana king's peel is $47: 64=0.734$ or $73.4 \%$ from the criteria expected of $100 \%$ with fair good predicate. From the flavor aspect obtained amount of data 14, thus flavors score of jam made from banana king's peel is 14: $16=0.875$ or $87.5 \%$ of the expected criteria was very tasty. From the aroma aspect obtained the amount of data 12, thus aroma score was $12: 16=0.75$ or $75 \%$ of the expected criteria was quite fragrant. From the color aspect obtained the amount of data 11, thus color score was $11: 16=0.687$ or $68.7 \%$ of the expected criteria was quite brown. From the texture aspect, the data obtained is 10, thus texture score is $10: 16=0.625$ or $62.5 \%$ of the expected criteria was quite thick. The average score of the jam made from banana king's peel as in Table II.

TABLE II. AVERAGE SCORE OF JAM MADE FROM BANANA KING'S PEEL

\begin{tabular}{ll}
\hline \multicolumn{1}{c}{ Parameter } & \multicolumn{1}{c}{ Jam made from Banana King's Peel } \\
\hline Flavor & $87,5 \%$ \\
Aroma & $75 \%$ \\
Color & $68,7 \%$ \\
Texture & $62,5 \%$ \\
Average & $73,4 \%$ \\
\hline
\end{tabular}

Based on Table II shown that the experiment of making score of jam made from banana king's peel, the result is that jam made from banana king's peel obtained an average score of $73.4 \%$ which is viewed from flavor, aroma, color and texture aspects. Based on the results of the endurance test products to determine the quality of taste, aroma and texture of jam made from banana king's peel need to be tested. The method used to examine the endurance store of jam made from banana king's peel by incorporated into the plastic cup packaging with an airtight lid and stored in the refrigerator and will be allowed to stand for one week. From the result, obtained on the first day until the seventh that the jam still in good taste, in sharp aroma and creamy texture.

\section{B. Discussion}

Based on data analysis conducted by four panelists can be found from organoleptic test toward jam quality made from banana king's peel assessed by four panelists in flavor indicator that is respondents answering very tasty (4) $=2 \times 4=8$, respondents answering quite tasty $(3)=2 \times 3=6$, respondents answering less good $(2)=0$ and respondents who answered bad $(1)=0$. Total score of flavor category is $8+6+0+0=14$, thus from the table interval values of the organoleptic test can be concluded for flavor category is Very Tasty. In aroma or scent indicator, respondents answering very fragrant $(4)=2 \times 4$ $=8$, respondents answering quite fragrant $(3)=0$, respondents answering less fragrant $(2)=2 \times 2=4$ and respondents answering bad $(1)=0$. Total score of aroma category is $8+0+$ $4+0=12$, thus from the table interval values of the organoleptic test can be concluded for aroma category is Quite Fragrant. In color indicator, respondents answering brown (4) = 0 , respondents answering pretty brown $(3)=3 \times 3=9$, respondents answering less brown (2) = 1 × $2=2$ and respondents answering not brown $(1)=0$. Total score of color category is $9+0+2+0=11$, from the table interval values of the organoleptic test can be concluded for the color category is Pretty Brown. In texture indicator, respondents answering very thick $(4)=0$, respondents answering quite thick $(3)=2 \times 3=6$, respondents answering less thick $(2)=2 \times 2=4$ and respondents answering not thick $(1)=0$. Total score of texture category is $6+4+0+0=10$, thus from the table interval values of the organoleptic test can be concluded for texture category is Quite Thick. 


\section{CONCLUSION}

Based on the results of the research quality of jam made from banana skins from the quality of taste, aroma, color and texture found the final assessment result above. It can be concluded that the quality jam made from banana king's peel get a fairly good value. In which the flavor score is $87.5 \%$, aroma $75 \%$, color $68.7 \%$ and texture obtained $62.5 \%$. Thus in this research, banana king's peel can be used as raw material in the manufacture of jam because it is easily obtained banana king's peel waste and add variations in the manufacture of jam. The endurance of jam made from banana king's peel may persist one week if we put into the refrigerator.

\section{REFERENCES}

Alhumaira, Adipura. (2014). Studi Eksperimen Pembuatan Selai dengan Bahan Dasar Tape Ketan Hitam dan Tape Ketan Kuningan Serta Daya Terima Konsumennya. Bandung: Universitas Pendidikan Indonesia.

BSN. Selai Buah SNI 3746:2008. Jakarta: Badan Standarisasi Nasional.
Munadjin. (1998). Teknik Pengolahan Pisang. Jakarta: PT Gramedia Pusataka Utama.

Mulyatiningsih, E. (2012). Riset Terapan. Yogyakarta: UNY Press.

Muslich. (2010). Metode Pengambilan Keputusan Kuantitatif. Jakarta: Bumi aksara.

Noviagustin. Leyla et.all (2008). Pemanfaatan Limbah Pisang Sebagai Subtituen Tepung Terigu dalam Pembuatan Mie. Retrieved on 10 June 2016 from https://www.scribd.com/doc/22590581/Kulit-Pisang-tgl16-11-09

Noerhatati, et.all. (2009). Pembuatan Selai Salak (Salacca Edulis Reinw): Kajian Dari Penambahan Natrium Benzoat Dan Gula Yang Tepat Terhadap Mutu Selai Salak Selama Penyimpanan. Surabaya: Universitas Wijaya Kusuma.

Sugiyono. (2010). Metodologi Penelitian Kuantitatif Kualitatif dan $R \& D$. Jakarta: Alfabeta

Strauss, Anselm dan Juliet Corbin, (2003). Dasar-dasar Penelitian Kualitatif. Yogyakarta: Pustaka 